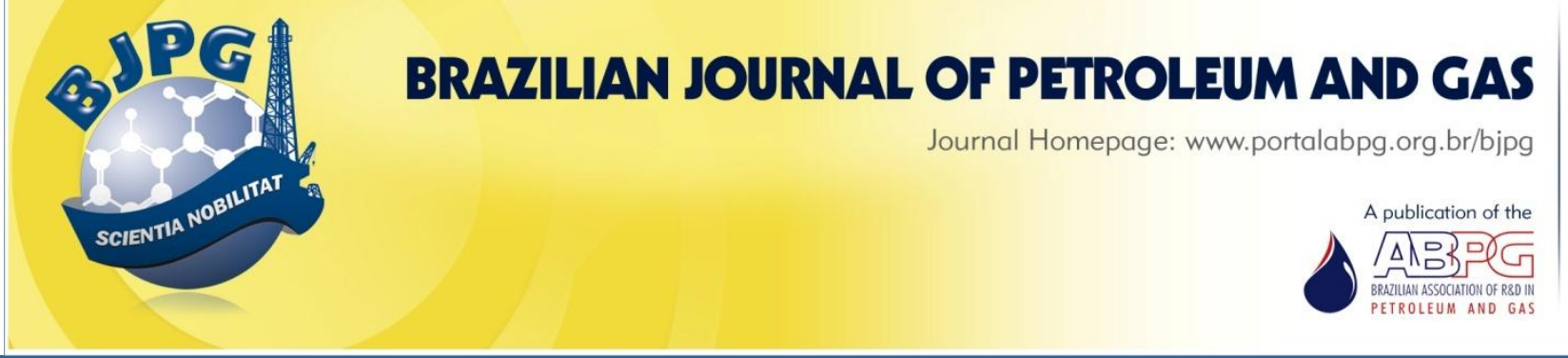

\title{
ASSESSMENT OF METAL RECOVERY FROM RAW SPENT HYDRODESULFURIZATION CATALYST THROUGH BIOLEACHING AND CHEMICAL LEACHING
}

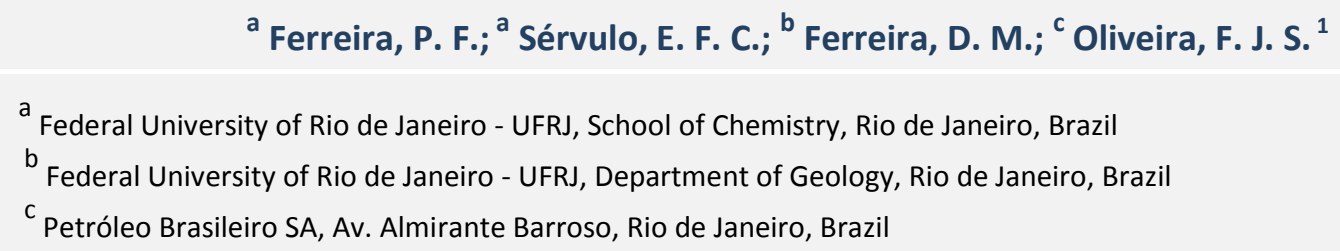

\section{ABSTRACT}

The aim of this work is to evaluate the recovery of metals from a spent catalyst of diesel hydrodesulfurization (HDS), without any chemical, thermal, or physical pre-treatment, using the Acidithiobacillus thiooxidans FG-01 strain and chemical leaching. The spent catalyst is a hazardous waste due to the presence of organochlorine compounds, petroleum hydrocarbons, and heavy metals. Chemical leaching tests were performed with solutions of citric acid $\left(20 \mathrm{~g} \mathrm{~L}^{-1}\right)$, oxalic acid $\left(20 \mathrm{~g} \mathrm{~L}^{-1}\right)$, citric and oxalic acid mixture $\left(1: 1,20 \mathrm{~g} \mathrm{~L}^{-1}\right)$, and sulfuric acid $\left(10 \mathrm{~g} \mathrm{~L}^{-1}\right)$. The best results of metals recovery through chemical reaction were obtained when using the inorganic acid solution. The two-step bioleaching assays were conducted in $500 \mathrm{~mL}$ Erlenmeyer flasks, with a pulp density of $27.5 \mathrm{~g} \mathrm{~L}^{-1}$, and a sulfuric acid concentration of $20 \mathrm{~g} \mathrm{~L}^{-1}$. There were no differences between chemical and microbial leaching results. The A. thiooxidans FG-01 is a promising strain due to the recovery of $\mathrm{Al}(\sim 65 \%), \mathrm{V}(\sim 25 \%)$, and $\mathrm{Mo}(\sim 25 \%)$ from the raw solid residue.

\section{KEYWORDS}

value metals recovery; metals leaching; bioleaching; spent hydrodesulfurization catalyst; Acidithiobacillus thiooxidans

\footnotetext{
${ }^{1}$ To whom all correspondence should be addressed.

Address: Petróleo Brasileiro SA, Av. Almirante Barroso, 81, Floor 23, Centro, Rio de Janeiro, Brazil | Zip Code: 20031-004 |e-mail: f.oliveira@petrobras.com.br doi:10.5419/bjpg2015-0014
} 


\section{INTRODUCTION}

The heterogeneous catalysis is an essential process for oil refineries to obtain fractions rich in hydrocarbons, with higher added value. During operations, the catalysts become disabled due to erosion and impregnation with impurities and are, later, sent to on-site or off-site regeneration plants. When regeneration is no longer possible, the catalysts are called spent catalysts and are considered a solid waste. It is estimated that there is an annual generation between 150,000 and 170,000 tons of this type of solid waste by oil refineries (Marafi \& Stanislaus, 2008).

The hydroprocessing catalysts are specially important among the spent catalysts generated by oil refining due to the quantity generated and the presence of heavy metals and other toxic substances in its composition (Srichandan et al., 2014; Asghari et al., 2013). The reactivity of these solid wastes with atmospheric air and the concentration of substances harmful to human health make these materials hazardous (Noori et al., 2014).

In addition to environmental issues, there is also a special concern in economic and strategic levels, given the content of valuable heavy metals present in such waste. Thus, the recovery of metals from spent catalysts can be a source of commercially valuable metals, reducing new openings of areas degraded by mining.

Some studies indicate chemical leaching using inorganic or organic acids (Ognyanova et al., 2009; Mirsha et al., 2010; Srichandan et al., 2014a) and microbial leaching (Jadhav \& Hocheng, 2012; Noori et al., 2014) as promising alternatives for the recovery of metals from spent catalysts. However, these works report chemical or biotechnological processes from oil refining spent catalysts pretreated with operations such as washing with solvents, heat treatment, and milling or sieving (Srichandan et al., 2014b; Thosar et al., 2014; Bharadwaj \& Ting, 2013). Pre-treatment operations may increase the metal recovery process cost on an industrial scale. The aim of this innovative study is to assess chemical leaching, using oxalic acid $\left(20 \mathrm{~g} \mathrm{~L}^{-1}\right)$, citric acid $\left(20 \mathrm{~g} \mathrm{~L}^{-1}\right)$, oxalic and citric acid mixture $\left(20 \mathrm{~g} \mathrm{~L}^{-1}\right)$, sulfuric acid $\left(10 \mathrm{~g} \mathrm{~L}^{-1}\right)$, and leaching using a wild Brazilian strain
Acidithiobacillus thiooxidans, coded as FG-01, in the recovery of heavy metals from crude spent HDT catalyst, that is, without any chemical, thermal, or physical pre-treatment.

\section{MATERIALS AND METHODS}

\subsection{Spent HDS catalyst}

This study used a spent HDS catalyst generated in a diesel treatment unit from a Brazilian oil refinery. The $200 \mathrm{~kg}$ sample was received in raffia bag and subsampled using a trier type sampler to obtain $5 \mathrm{~kg}$ of the solid residue. Coning and quartering procedure was performed to obtain 0.5 $\mathrm{kg}$ of sample that was stored in glass vials $\left(5 \pm 1^{\circ} \mathrm{C}\right)$.

Aliquots of $0.1 \mathrm{~g}$ of spent catalyst were digested in a mixture of nitric acid, hydrochloric acid, and hydrogen peroxide using a microwave to obtain acid digested samples. These samples were analyzed by atomic absorption spectrometry (AAS) using a Perkin-Elmer model 300 AAnalyst to determine their chemical elements.

Aliquots of spent catalyst (1 g) were also subjected to ultrasonic extraction with ultrapure dichloromethane, and cleaned by silica gel column chromatography before the determinations of organic substances. The total hydrocarbon concentrations were determined by gas chromatography using a Thermo Finnigan Focus GC gas chromatograph, equipped with column and flame ionization detector. The chlorinated organic compounds were quantified using the same instrument, equipped with column and an electron capture detector. Polycyclic aromatic hydrocarbons (PAHs), benzene, xylenes, and ethylbenzene were quantified by gas chromatography coupled to mass spectrometry, using a Thermo Finnigan, Focus GC / Thermo Finnigan, Focus DSQ.

Table 1 shows the chemical characterization of the spent HDS catalyst. The presence of high concentrations of $\mathrm{Al}, \mathrm{Mo}$, and $\mathrm{Co}$ in the catalyst, allow one to infer that it is a Co-Mo catalyst supported on alumina. Benzene and toluene were present in samples at concentration values below the limit of detection (LOD), $0.25 \mathrm{mg} / \mathrm{kg}$, probably due to the volatilization in the central waste storage facility of the refinery. 
Table 1. Composition of the spent hydrodesulfurization catalyst from a Brazilian oil refinery.

\begin{tabular}{ll}
\hline Parameter & Result $\left(\mathrm{mg} \mathrm{kg}^{-1}\right)$ \\
\hline Total aluminum & $22 \pm 2^{*}$ \\
Total cobalt & $10 \pm 1^{*}$ \\
Total mercury & $0.2 \pm 0.1$ \\
Total molybdenum & $16 \pm 1^{*}$ \\
Total nickel & $387 \pm 28$ \\
Total vanadium & $120 \pm 17$ \\
Sulfides & $181 \pm 2^{*}$ \\
Total Petroleum Hydrocarbons & $240 \pm 27^{*}$ \\
10 Polycyclic Aromatic Hydrocarbons & $101 \pm 33^{* *}$ \\
Ethylbenzenes & $21 \pm 1$ \\
Xylenes & $64 \pm 2$ \\
Trichlorophenol & $20 \pm 2$ \\
Tetrachlorophenol & $25 \pm 2$ \\
\hline$*$ g kg & \\
$* *$ Sum of the concentration of 10 priority PAHs of the Dutch Legislation
\end{tabular}

Samples of the catalyst, before and after treatment by chemical leaching and microbial leaching, were analyzed by energy dispersive x-ray spectroscopy (EDS) and scanning electron microscopy (SEM). Before performing the microscopic analysis, the samples were dried at $37^{\circ} \mathrm{C}$ and subsequently coated with silver. The observation of the catalyst particles was carried out using a scanning electron microscope (Zeiss DSM 940) equipped with EDX Link detector and a Kontron (Zeiss) automatic image analysis system, under the following conditions: $\mathrm{HV}=25 \mathrm{kV}$, mode $\mathrm{SE}, \mathrm{WD}=12.4$ to $13.0 \mathrm{~mm}$. The specific chemical analyzes were obtained by EDS (Oxford Link L300) with a Sili detector Pentafet and an ultrathin window ATW2, with $45 \mathrm{cps} / \mathrm{eV}$ (y-axis) x $18 \mathrm{keV} \mathrm{(x}$ axis) of resolution, coupled to SEM.

\subsection{Chemical leaching tests}

Chemical leaching tests were performed with organic (citric, oxalic) or inorganic (sulfuric) acids, considering the possibility of obtaining them microbiologically. In the case of organic acids, solutions were used at the concentration of $20 \mathrm{~g} \mathrm{~L}^{-}$ 1 , and the mixture in the ratio $1: 1\left(v v^{-1}\right)$, so that the final concentration was also $20 \mathrm{~g} \mathrm{~L}^{-1}$. The concentration of sulfuric acid was set at $10 \mathrm{~g} \mathrm{~L}^{-1}$ to obtain a $\mathrm{pH}$ value similar to the solutions prepared with organic acids $(\mathrm{pH}=1)$.

The leaching tests were conducted in triplicate in $500 \mathrm{~mL}$ Erlenmeyer flasks containing $100 \mathrm{~mL}$ of the acid solution and $2.75 \mathrm{~g}$ of the spent HDT catalyst. The flasks were kept under shaking condition (150 rpm) for 30 minutes at $29 \pm 1^{\circ} \mathrm{C}$. The acid leaching solutions were subsequently filtered through $0.22 \mu \mathrm{m}$ membranes and aliquots were used for the determination of metal concentrations by AAS using Perkin-Elmer model AAnalyst 300. All assays were conducted in triplicate and the results were presented as the mean value with standard deviation.

\subsection{Leaching solution production}

This work used an Acidithiobacillus thiooxidans FG-01 strain isolated from a uranium mine in Brazil (Garcia Jr., 1991). The bacterial strain was stored in T\&K liquid medium (Tuovinen \& Kelly, 1973) at $5 \pm$ $1^{\circ} \mathrm{C}$, and subcultured every two months.

The freshly prepared T\&K medium was sterilized at $121^{\circ} \mathrm{C}$ for $20 \mathrm{~min}$ and, then, the supplement with elemental sulfur (previously treated at $110^{\circ} \mathrm{C}$ for 1 h) was added to obtain a concentration of $10 \mathrm{~g} \mathrm{~L}^{-1}$ $\left(S^{0}\right)$. 
The inoculums preparation consisted of activation and propagation of $10 \mathrm{~mL}$ of the stock culture into $100 \mathrm{~mL}$ of mineral medium $(\mathrm{pH}=2$, adjusted with $\mathrm{H}_{2} \mathrm{SO}_{4} \quad 0.5 \mathrm{~mol} \mathrm{~L}^{-1}$ ) in $500 \mathrm{~mL}$ Erlenmeyer flasks. Next, the cultures were incubated at $29 \pm 1^{\circ} \mathrm{C}$ in a thermostatic incubator shaker (CIENTEC, CT-712R Model) at $150 \mathrm{rpm}$ for 4 days.

To obtain the leaching solutions, Erlenmeyer flasks of $500 \mathrm{~mL}$ capacity containing $100 \mathrm{~mL}$ of the medium and a volume of inoculum enough to establish an initial concentration of $10^{5}$ cells $\mathrm{mL}^{-1}$ were used. The flasks were shaken in an incubator table at $29 \pm 1^{\circ} \mathrm{C}$ and $150 \mathrm{rpm}$ for 7 days when the maximum amount of sulfuric acid concentration $\left(40 \mathrm{~g} \mathrm{~L}^{-1}\right)$ was reached. Throughout the process, the cell concentration was determined using a Neubauer chamber (Mousavi et al., 2008). After 7 days, the fermented medium was filtered in polyacetate membranes (Millipore, $0.22 \mu \mathrm{m}$ pore size) and diluted to obtain solutions with acid concentrations of $20 \mathrm{~g} \mathrm{~L}^{-1}$. Abiotic control tests were also performed.

\subsection{Bioleaching tests}

Bioleaching tests were conducted in two phases. First, it was produced the acid phase using the $A$. thiooxidans $\mathrm{FG}-01$ strain, as previously described. Second, the contact of the microbial leaching solution with the spent catalyst phase. Thus, diluted leaching solutions were transferred to $500 \mathrm{~mL}$ Erlenmeyer flasks in which amounts of catalyst were added to establish a pulp density of $27.5 \mathrm{~g} \mathrm{~L}^{-1}$. The flasks were shaken in a thermostatic incubator table (CIENTEC, Model CT-712R) at $29 \pm$ $1^{\circ} \mathrm{C}$ and $150 \mathrm{rpm}$ for 4 days. In all cases, replicas were employed using sacrificial flasks and the concentrations of $\mathrm{Al}, \mathrm{Co}, \mathrm{Mo}, \mathrm{Ni}$, and $\mathrm{V}$ were monitored in the solutions throughout the tests. For this, $25 \mathrm{~mL}$ aliquots of the suspension were removed from the flasks and filtered through polyacetate membranes (Millipore, $0.22 \mu \mathrm{m}$ pore size) before the determinations. The results are presented as the mean value and standard deviation of three independent tests.

The $\mathrm{pH}$ measurements were performed using a Digimed potentiometer, DMPH-1 model, equipped with a glass combination electrode (platinum working electrode and $\mathrm{Ag}^{\circ} / \mathrm{AgCl}$ reference electrode). Between the $\mathrm{pH}$ measurements, and prior to the calibration with buffer solutions, the electrodes were immersed in a $5 \% \mathrm{v} / \mathrm{v}$ formaldehyde solution for 30 minutes for decontamination purposes. The acidity of the medium samples were determined by titration with $0.1 \mathrm{~mol} \mathrm{~L} \mathrm{~L}^{-1} \mathrm{NaOH}$ using $0.1 \mathrm{~mL}$ of phenolphthalein as indicator. The metal concentrations were determined by AAS, PerkinElmer, AAnalyst 300 model.

\subsection{Statistical analysis}

The results for the average metal recovery obtained in the indirect bioleaching tests, as a function of the pulp density of the crude spent catalyst, were submitted to analysis of variance (ANOVA) and multiple comparisons of means (Tukey Test), under a completely randomized design, at the $5 \%$ significance level. In all cases, the analyses were carried out with the aid of the computational software program Statistica, version 5.5 (StatsoftInc).

\section{RESULTS AND DISCUSSIONS}

Table 2 shows the results of multiple comparisons of mean concentrations of $\mathrm{Al}, \mathrm{Mo}, \mathrm{Ni}$, and $\mathrm{V}$ in the leaching solutions. Analysis of variance indicated a least significant difference (LSD) of 0.5 $\mathrm{mg} \mathrm{L}^{-1}$ for $\mathrm{Al} ; 0.3 \mathrm{mg} \mathrm{L}^{-1}$ for Mo, $0.5 \mathrm{mg} \mathrm{L}^{-1}$ for $\mathrm{Ni}$,

Table 2. Concentration of metals in the leaching solution after 30 min of contact.

\begin{tabular}{lllll}
\hline Leaching solutions & $\mathrm{Al}\left(\mathrm{mg} \mathrm{L}^{-1}\right)$ & $\mathrm{Mo}\left(\mathrm{mg} \mathrm{L}^{-1}\right)$ & $\mathrm{Ni}\left(\mathrm{mg} \mathrm{L}^{-1}\right)$ & $\mathrm{V}\left(\mu \mathrm{g} \mathrm{L}^{-1}\right)$ \\
\hline Citric acid $\left(20 \mathrm{~g} \mathrm{~L}^{-1}\right)$ & $2.0^{\mathrm{b}}$ & $7.5^{\mathrm{a}}$ & $8.4^{\mathrm{b}}$ & $9.2^{\mathrm{b}}$ \\
Oxalic acid $\left(20 \mathrm{~g} \mathrm{~L}^{-1}\right)$ & $1.3^{\mathrm{c}}$ & $3.0^{\mathrm{b}}$ & $1.1^{\mathrm{c}}$ & $7.1^{\mathrm{c}}$ \\
Citric and oxalic acids $\left(20 \mathrm{~g} \mathrm{~L}^{-1}\right)$ & $2.0^{\mathrm{b}}$ & $3.6^{\mathrm{b}}$ & $8.1^{\mathrm{b}}$ & $8.8^{\mathrm{b}}$ \\
Sulfuric acid $\left(10 \mathrm{~g} \mathrm{~L}^{-1}\right)$ & $3.0^{\mathrm{a}}$ & $2.1^{\mathrm{c}}$ & $9.5^{\mathrm{a}}$ & $12.7^{\mathrm{a}}$ \\
\hline
\end{tabular}

Note: For the same column, the same lowercase letters indicate that the data did not differ significantly by Tukey test $(p>0.05)$ 
and 1.2 ug $\mathrm{L}^{-1}$ for $\mathrm{V}$, with a standard deviation of 0.1 for the first three elements and 0.3 for $V$. Tukey test proved, based on the multiple comparisons of means ( $p<0.05)$, that the type of leaching solution used influenced the solubilization of the studied metals, and that the inorganic acid allowed the highest metals recovery, with the exception of Mo.

According to Table 2, the citric acid led to greater recovery of metals among the organic acids tested. Note that when using the mixture of acids, the citric acid enhanced the action of the oxalic acid. These results are in disagreement with those reported by Santhiya and Ting $(2006 ; 2005)$. These authors showed better metal recoveries with the use of oxalic acid solutions in comparison with tests carried out with citric acid solutions. They suggest that most of the leaching capacity of the oxalic acid could be attributed to the higher protonic strength (pKa $=1.2$ and 3.15 to oxalic and citric acids, respectively). In this study, the best performance of the citric acid compared to the oxalic acid should probably be related to: the presence of a higher number of carboxyl groups that can act in the formation of coordinate covalent bonds with metal cations. Another possibility is the polarity, which may have facilitated the removal of organic substances from the pores of the catalysts (Table $1)$, allowing better contact with the solid matrix and, therefore, the leaching of metals.

The results of this work establish that the metal recoveries from the spent HDT catalyst by chemical action can be represented as: sulfuric acid $>$ citric acid> mixture of citric:oxalic acid > oxalic acid. The sulfuric acid solution allowed the extraction of approximately $3 \%$ of $\mathrm{Al}, 11 \%$ of $\mathrm{Ni}, 10 \%$ of $\mathrm{V}$, and $3 \%$ of Mo. These results are promising mainly due to the low contact time $(30 \mathrm{~min})$, the absence of chemical, thermal, or physical pretreatment of the samples, which is adopted in most of the work related to this subject (Mishra et al., 2007; RojasRodriguez et al., 2012), and the agitation by ultrasound (Marafi \& Stanislaus, 2008; Oza \& Patel, 2012). Castro et al. (2000), in their study, were able to solubilize $46 \%$ of $\mathrm{Ni}$ from a rocky material (garnierite- $\mathrm{SiO}_{2}$ ) after 7 days of treatment with $\mathrm{H}_{2} \mathrm{SO}_{4}(\mathrm{pH}$ 1.0). However, they used a natural material and not an industrial waste. The authors also reported a high recovery percentage with the use of organic acids at a concentration of $100 \mathrm{mM}$ : $36 \%$ with citric acid; $24 \%$ with oxalic acid; and $23 \%$ with a mixture of oxalic/citric acid. The chemical leaching of $50 \mathrm{~g} \mathrm{~L}^{-1}$ spent catalyst (pre-treated with solvent) using sulfuric acid ( $\mathrm{pH} 1.68)$, performed by Mishra et al. (2007), was able to recover $32 \%$ of Mo after 7 days. However, the origin of the catalyst was not disclosed and the catalyst was pre-treated for the removal of organics. The tests performed by Santhiya and Ting (2006) showed that the leaching of $10 \mathrm{~g} \mathrm{~L}^{-1}$ of a spent and ground $\mathrm{NiMoP} / \mathrm{Al}_{2} \mathrm{O}_{3}$ catalyst for $24 \mathrm{~h}$ was $52.2 \%$ and $60.2 \%$ for $\mathrm{Al}, 88.1 \%$ and $60.8 \%$ of $\mathrm{Ni}$, and $20.6 \%$ and $82.2 \%$ of $\mathrm{Mo}$ for the citric and oxalic acids, respectively.

Based on a comparison of the results obtained in this study with those reported in the literature, the $A$. thiooxidans FG-01 strain was selected for microbial leaching, due to its potential in the production of such inorganic acid.

\subsection{Production of acid leach by $A$. thiooxidans FG-01}

The bacterial strain had the highest specific growth rate after five days of culture in mineral medium T\&K (without supplementation with the spent catalyst), reaching the maximum concentration of $3 \times 10^{7} \mathrm{~mL}^{-1}$ cells and an exponential growth profile in this period (data not shown). The production of the acid was associated with microbial growth and a concentration of sulfuric acid of about $40 \mathrm{~g} \mathrm{~L}^{-1}$ was achieved $(\mathrm{pH} 1)$. Moura et al., (2008) also observed that the growth of sulfur-oxidizing bacteria, in the medium $9 \mathrm{~K}$ (Silverman \& Lundgren, 1959), resulted in increased acidity, but the minimum $\mathrm{pH}$ value of 1.0 was reached only after 20 days. Thus, it is evident the potential of $A$. thiooxidans $\mathrm{FG}-01$ in acid production promoting the leaching of metals from solid waste. Another fact that is worth noting is that the mineral medium used in this study consists of a small amount of nutrients, which can aid in the economics of the process.

\subsection{Microbial leaching}

Krebs et al. (1997) reported that the microbial leaching process is based on three principles: transformation through the action of the produced acids, oxidation and reduction reactions, and generation of oxidizing agents. Thus, this process may be employed in the recovery of metals and it is conducted generally in one or two-step processes (also termed direct and indirect leaching, respectively). The main advantage of the indirect 


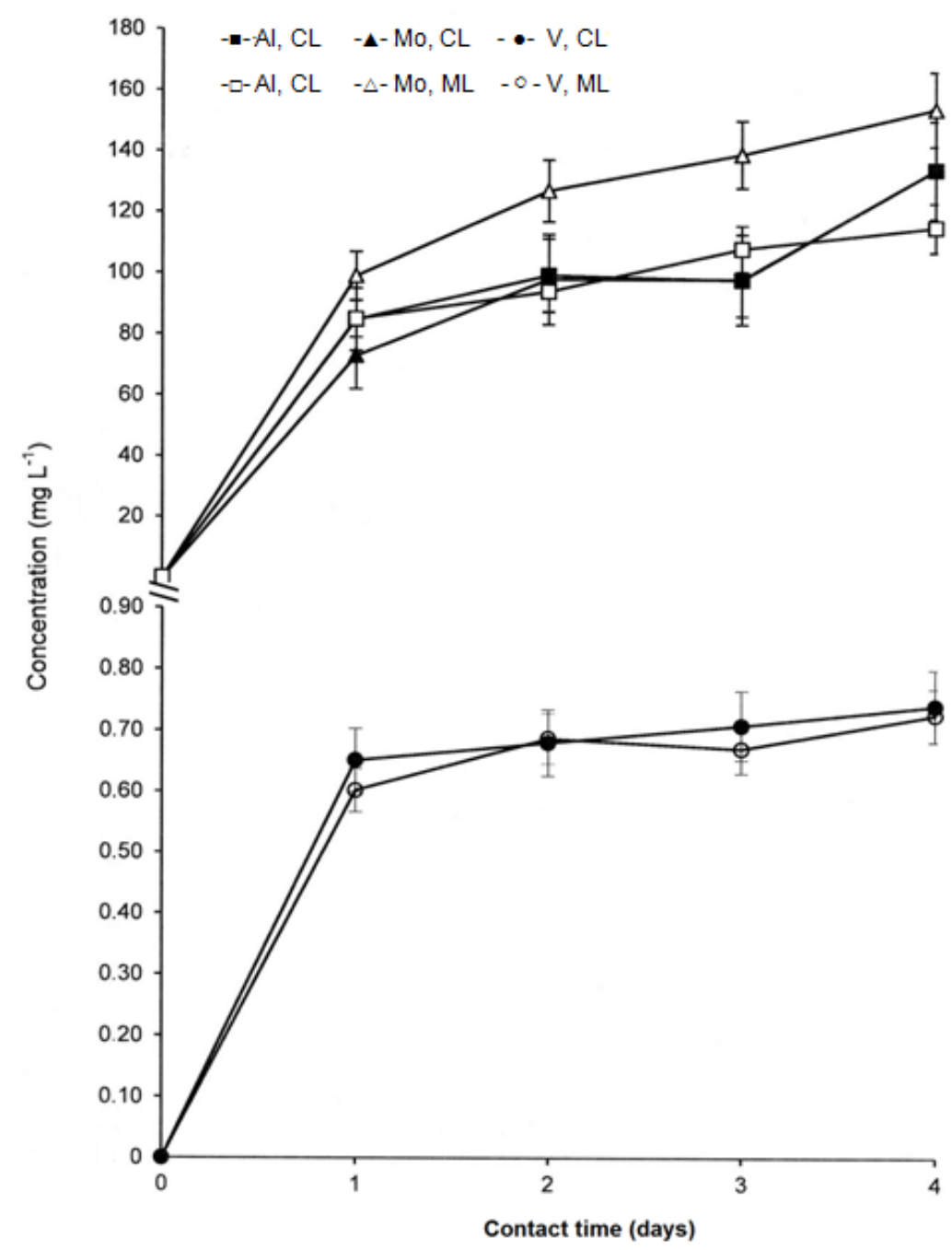

Figure 1. Chemical leaching $(C L)$ and indirect bioleaching $(\mathrm{ML})$ of crude spent HDT catalyst (pulp density of $27.5 \mathrm{~g}$ $\left.\mathrm{L}^{-1}\right)$, sulfuric acid concentration $\left(20 \mathrm{~g} \mathrm{~L}^{-1}\right)$.

bioleaching process over the one step process is the fact that the microbial cultivation in a toxic environment can be avoided. Microbial growth in the presence of a dangerous solid waste may not be favorable to the formation of acid and can negatively influence the efficiency of the bioprocess (Amiri et al., 2011; Bharadwaj \& Ting, 2013).

A. thiooxidans is recognized as a potential producer of sulfuric acid, which is considered one of the main factors in the mobilization of metals from a solid to a liquid phase in a bioleaching system (Crundwell, 2003). It is also known that bacteria of this genus are able to produce phosphatidylinositol and other surfactants metabolites, which can also assist in the recovery of metals from solid matrices (Fazzini et al., 2011).
It is also important to note that, regardless of the conditions tested, there was no significant recovery of $\mathrm{Ni}$ and $\mathrm{Co}$ of the catalyst, even though the residue was rich in these elements, reason why these data are not presented. Thus, the $A$. thiooxidans FG-01 strain cannot be considered promising for the recovery of $\mathrm{Ni}$ and $\mathrm{Co}$ from the solid residue tested. Figure 1 shows the recovery of $\mathrm{Al}, \mathrm{Mo}$, and $\mathrm{V}$ from the spent HDT catalyst in tests conducted with pulp density of $27.5 \mathrm{~g} \mathrm{~L}^{-1}$ by the action of sulfuric acid solution and leaching solution containing sulfuric acid at the same concentration. According to the figure, there is no significant difference between chemical and microbial leaching in the recovery of the analyzed elements. Moreover, after 1 day of contact, the increase of time promoted only a small increase in the removal of $\mathrm{V}$. 


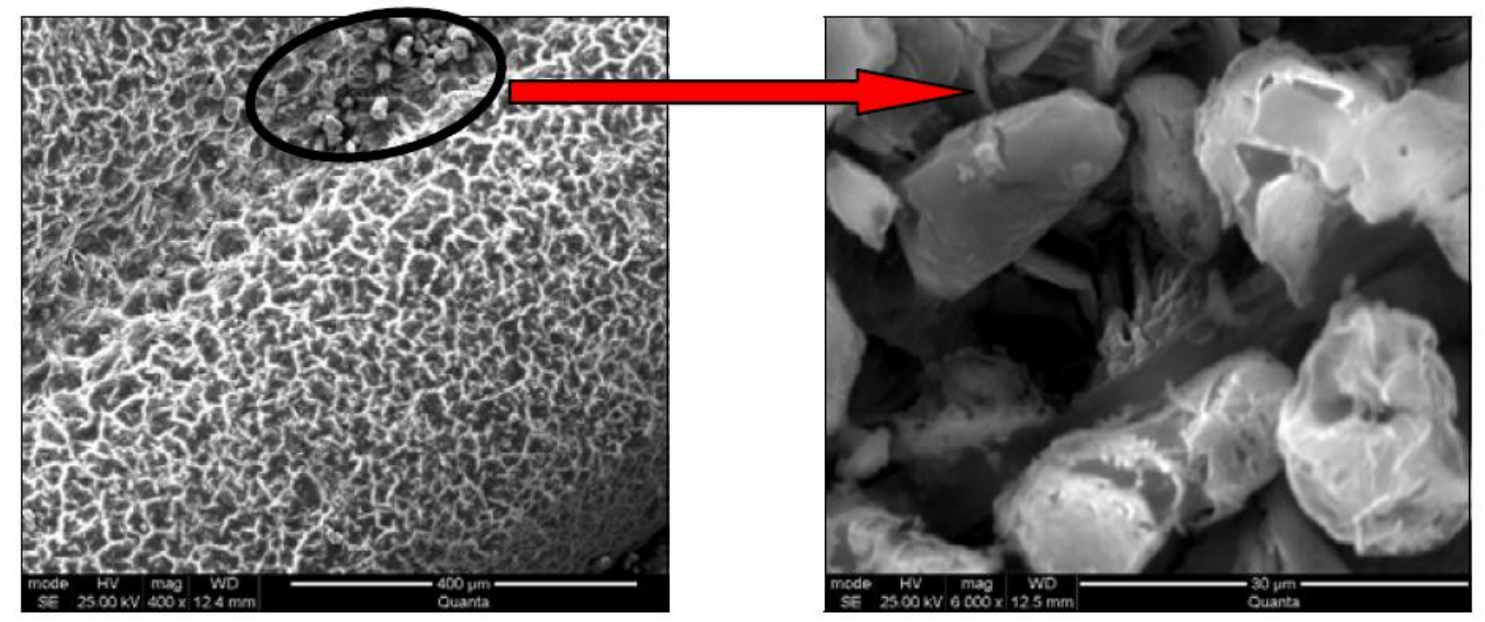

Figure 2. Analysis by SEM (6000X) of a specific area of the sample treated with acid produced by $A$. thiooxidans FG01.

As shown in Figure 1, one can point out that Mo was the metal with the highest percentage of recovery. Taking into account the mass of spent catalyst and the volume of leaching solution per flask, and also the solid waste chemical composition (Table 1), the removal of Mo from catalyst by microbial activity was $46 \%$, after 4 days. Beolchini et al. (2010) reported microbial leaching of Mo from spent HRT catalysts of less than 30\% after 20 days of contact. These results corroborate those presented by Mishra et al. (2007) who obtained the maximum recovery of about $71 \%$ on tests conducted with $5 \mathrm{~g} \mathrm{~L}^{-1}$ of spent pre-treated HDS catalyst, in two steps, and 7 days of contact. Thus, the performance of the $A$. thiooxidans FG-01 strain is considered to be promising since a high Mo recovery was obtained after only 1 day of contact.

Vanadium and Aluminum were removed from the solid matrix at a similar percentage (24-27\%). Studies show that Al bioleaching can be performed in culture of $A$. thiooxidans and some fungi genera, with recovery percentages ranging from $30 \%$ to 40\% (Aung \& Ting, 2005; Santhiya \& Ting, 2005). Higher recovery values for $\mathrm{V}(>90 \%)$ were reported by Kim et al. (2009). However, all of these researches employed spent catalysts that were chemically, physically, or thermally pretreated and the processes were conducted for more than four days.

The analysis of the accumulated materials on the surfaces of the spent catalyst samples through
EDS identified several chemical elements, especially oxygen, which increased from $21 \%$ in the samples prior to the biotreatment to $65 \%\left(\mathrm{~m} \mathrm{~m}^{-1}\right)$ after the bioleaching process. When the chemical leaching was performed, the concentration was approximately $54 \%$, probably due to the removal of the adsorbed heavy metals and the permanence of the support material $\left(\mathrm{Al}_{2} \mathrm{O}_{3}\right)$. Figure 2 shows the magnified image (6000X) of the layer adhered to the surface of the catalyst after the treatment with the leaching solution obtained from the cultivation of $A$. thiooxidans $\mathrm{FG}-01$. It is possible to visualize the presence of cells, with the same morphological characteristic to this specie, attached to the deposited material.

The concentration of the others quantified metals ( $\mathrm{Al}, \mathrm{Mo}$, and $\mathrm{V}$ ) was reduced, regardless of the treatment. It is worth noting that the EDS technique only quantifies the elements arranged in the surface layer of solids, not reaching elements arranged in micropores of the catalyst. For this reason one can infer that the leaching process, although effective, occurred mainly on the surface of the spent catalyst.

\section{CONCLUSIONS}

The acid leaching solution produced by the $A$. thiooxidans FG-01 strain was able to recover Al ( 28\%), Mo ( 46\%), and V ( 25\%) from spent HDS catalyst without any chemical, thermal, or physical pre-treatment. The increase in contact time from 1 
up to 4 days showed small increase in the removal of $\mathrm{V}$. In the case of $\mathrm{Al}$ and Mo, the increase of time to 4 days enhanced the recovery. However, it was not possible to recover $\mathrm{Co}, \mathrm{Cu}$, and $\mathrm{Ni}(<5 \%)$ in any of the conditions tested in this study. In these experimental conditions, the use of sulfuric acid solution or leaching solution produced by the microbial isolate did not influence the amount of metal recovered from the solid waste or the kinetic profile. Thus, it is evident the potential of the bacteria to recover $\mathrm{Al}, \mathrm{Mo}$, and $\mathrm{V}$ from the spent HDS catalyst.

\section{ACKNOWLEDGEMENTS}

We thank CAPES and CNPq for the financial support.

\section{REFERENCES}

Amiri, F., Yaghmaeia, S., Mousavi, S. M. Bioleaching of tungsten-rich spent hydrocracking catalyst using Penicillium simplicissimum, Bioresource Technology, v. 102, p. 1567-1573, 2011. http://dx.doi.org/10.1016/j.biortech.2010.08.087

Asghari, I., Mousavi, S. M., Amiri, F., Tavassoli, S. Bioleaching of spent refinery catalysts: A review. Journal of Industrial and Engineering Chemistry, v. 19, p. 1069-1081, 2013.

http://dx.doi.org/10.1016/j.jiec.2012.12.005

Aung, K. M. M., Ting, Y. Bioleaching of spent fluid catalytic cracking catalyst using Aspergillus niger. Journal of Biotechnology, v. 116, p. 159170, 2005.

http://dx.doi.org/10.1016/j.jbiotec.2004.10.008

Beolchini, F., Fontia, V., Ferella, F., Vegliò, F. Metal recovery from spent refinery catalysts by means of biotechnological strategies. Journal of Hazardous Materials, v. 178, p. 529-534, 2010. http://dx.doi.org/10.1016/j.jhazmat.2010.01.114

Bharadwaj, A., Ting, Y-P. Bioleaching of spent hydrotreating catalyst by acidophilic thermophile Acidianus brierleyi: Leaching mechanism and effect of decoking. Bioresource Technology, v. 130, p. 673-680, 2013.

http://dx.doi.org/10.1016/j.biortech.2012.12.047
Castro, I. M., Fietto, J. L. R., Vieira, R. X., Trópia, M. J. M., Campos, L. M. M., Paniago, E. B., Brandão, R. L. Bioleaching of zinc and nickel from silicates using Aspergillus niger cultures. Hydrometallurgy, v. 57, p. 39-49, 2000.

http://dx.doi.org/10.1016/S0304-386X(00)00088-8

Crundwell, F. K. How to bacteria interact with minerals. Hydrometallurgy, v. 71, p. 75-81, 2003. http://dx.doi.org/10.1016/S0304-386X(03)00175-0

Fazzini, R. A. B., Levican, G., Parada, P. Acidithiobacillus thiooxidans secretome containing a newly described lipoprotein Licanantase enhances chalcopyrite bioleaching rate. Applied Microbiology and Biotechnology, v. 89, p. 771-780, 2011. http://dx.doi.org/10.1007/s00253-010-3063-8

Garcia Jr, O. Isolation and purification of Thiobacillus ferrooxidans and Thiobacillus thiioxidans from some coal and uranium mines of Brazil. Revista de Microbiologia, v. 22, p.1-6, 1991.

Jadhav, U. U., Hocheng, H. A review of recovery of metals from industrial waste. Journal of Achievements in Materials and Manufacturing Engineering, v. 54 (2), p. 159-167, 2012.

Kim, D. J., Mishra, D., Ahn, J., Chaudhury, G. R., Ralph, D. E. A novel process to treat spent petroleum catalyst using sulfur-oxidizing lithotrophs. Journal of Environmental Science and Health Part A: Toxic/Hazardous Substances and Environmental Engineering, v. 44, p. 1585-1591, 2009. http://dx.doi.org/10.1080/10934520903263587.

Krebs, W., Brombacher, C., Bosshard, P. P., Bachofen, R., Brandl, H. Microbial recovery of metals from solids. FEMS Microbiology Reviews, v. 20, p. 605-617, 1997.

http://dx.doi.org/10.1111/j.1574-6976.1997.tb00341.x

Marafi, M. and Stanislaus, A. Spent hydroprocessing catalyst management: a review Part II. Advances in metal recovery and safe disposal methods. Resources, Conservation and Recycling, v. 53, p. 1-26, 2008.

http://dx.doi.org/10.1016/j.resconrec.2008.08.005

Mishra D., Chaudhury, G. R., Kim, D. J. Jong, G. A. Recovery of metal values from spent petroleum catalyst using leaching-solvent extraction technique. Hydrometallurgy, v. 101, p. 35-40, 2010.

http://dx.doi.org/10.1016/j.hydromet.2009.11.016 
Mishra, D., Kim, D. J., Ralph, D. E., Ahn, J. G., Rhee, Y. H. Bioleaching of vanadium rich spent refinery catalysts using sulfur oxidizing lithotrophs. Hydrometallurgy, v. 88, p. 202-209, 2007. http://dx.doi.org/10.1016/i.hydromet.2007.05.007

Moura, M. J., Ribeiro, B., Sousa, J., CostaFerreira $M$. Leaching of petroleum refinery ash by acidophilic sulfur-oxidizing microbial cultures. Bioresource Technology, v. 99, p. 8840-8843, 2008. http://dx.doi.org/10.1016/i.biortech.2008.04.043

Mousavi, S.M., Yaghmaei, S., Vossoughi, M., Roostaazad, R., Jafari, A., Ebrahimi, M., Chabok, O.H., Turunen, I., The effects of Fe(II) and Fe(III) concentration and initial $\mathrm{pH}$ on microbial leaching of low-grade sphalerite ore in a column reactor. Bioresource Technology, v. 99, p. 2840-2845 (2008). http://dx.doi.org/10.1016/j.biortech.2007.06.009

Noori, F. Z., Nematdoust, H. B., Amoabediny, G., Mousavi, S. M., Amouei T. M. An optimized integrated process for the bioleaching of a spent refinery processing catalysts. International Journal Environmental Research, v. 8, p. 621-634, 2014.

Ognyanova, A., Ozturk, A. T., De Michelis, I., Ferella, F., Taglieri, G., Akcil, A., Vegliò, F. Metal extraction from spent sulfuric acid catalyst through alkaline and acidic leaching. Hydrometallurgy, v. 100, p. 20-28, 2009.

http://dx.doi.org/10.1016/j.hydromet.2009.09.009

Oza, R., Patel S. Recovery of nickel from spent $\mathrm{Ni} / \mathrm{Al}_{2} \mathrm{O}_{3}$ catalysts using acid leaching, chelation and ultrasonication, Research Journal of Recent Sciences, v. 1, p. 434-443, 2012.

Santhiya, D., Ting, Y. Bioleaching of spent refinery processing catalyst using Aspergillus niger with high-yield oxalic acid. Journal of Biotechnology, v. 116, p. 171-184, 2005.

http://dx.doi.org/10.1016/i.jbiotec.2004.10.011

Santhiya, D., Ting, Y. Use of adapted Aspergillus niger in the bioleaching of spent refinery processing catalyst. Journal of Biotechnology, v. 121, p. 62-74, 2006.

http://dx.doi.org/10.1016/j.jbiotec.2005.07.002
Rojas-Rodríguez, A. D., Flores-Fajardo, O. González, F. S. A., Castillo, N. N. L., Gómez, M. J. C. Chemical treatment to recover molybdenum and vanadium from spent heavy gasoil hydrodesulfurization catalyst. Advances in Chemical Engineering and Science, v. 2, p. 408412, 2012. http://dx.doi.org/10.4236/aces.2012.23050

Silverman, M. P., Lundgren, D. G. Studies on the chemoautotrophic iron bacterium Ferrobacillus ferroxidans. I. An improved medium and a harvesting procedure for securing high cell yields. Journal Bacteriology, v. 77, p. 642-647, 1959.

Srichandan, H., Pathak, A., Kim, D. J., Lee, S-W. Optimization of two-step bioleaching of spent petroleum refinery catalyst by Acidithiobacillus thiooxidans using response surface methodology. Journal of Environmental Science and Health, Part A: Toxic/Hazardous Substances and Environmental Engineering, v. 49, p. 1740-1753, 2014a.

http://dx.doi.org/10.1080/10934529.2014.951264

Srichandan, H., Singh, S., Pathak, A., Kim, D. J., Lee, S-W., Heyes, G. Bioleaching of metals from spent refinery petroleum catalyst using moderately thermophilic bacteria: effect of particle size. Journal Environmental Science and Health Part A: Toxic/Hazardous Substances and Environmental Engineering, v. 49, p. 807-818, 2014b. http://dx.doi.org/10.1080/10934529.2014.882211

Thosar, A., Satpathy, P., Nathiya, T., Rajan, A. P. Biomining: a revolutionizing technology for a safer and greener environment. International Journal of Recent Scientific Research, v. 5 (9), p. 1624-1632, 2014.

Tuovinen, O. H., Kelly, D. P. Studies on the growth of Thiobacillus ferroxidans. I. Use of membrane filters and ferrous iron agar to determine viable number and comparison with $14 \mathrm{CO}_{2}$ - fixation and iron oxidation as measures of growth. Archives of Microbiology, v. 88, p. 285298, 1973. 